\title{
Editorial: The Blair years
}

\author{
Pensions (2007) 12, 171-173. doi:10.1057/palgrave.pm.5950061
}

There are a couple of things about history, First, it can take quite a while before the eventual impact of events becomes clear, as Mao Tse Tung is said to have said about the French Revolution. And secondly, history rarely packages itself in neat chunks. Wars do not start and stop in line with some formal calendar; earthquakes shatter continents according to their own individual timetable.

But the last ten years in pensions do seem to have marked a period that conveniently mirrors the Blair decade. Just look at some of the markers. 1997 was the year that the post-Maxwell legislation came into force (Pensions Act 1995), which rather like the Third Reich was supposed to last indefinitely. But it didn't even last as long as that; over the following decade we enjoyed or suffered a battery of reform which few could have anticipated at the time that Tony Blair defeated Militant Tendency and Old Labour and decided that Britain needed change.

We have change with a vengeance. Just to look at some of the major landmarks. The Pensions Act 1995 was really the first comprehensive pensions legislation in the UK following the publication of the Goode Report under the previous administration. But it took effect just a month before the 1997 general election and introduced a raft of changes including the minimum funding requirement, statements of investment policy, administration and reporting requirements, a new pensions regulator, a fraud compensation scheme, member-nominated trustees, and duties on professional advisers. Over 150 sections and seven schedules, it revolutionised the governance of defined benefit schemes, with the aim of ensuring that never again would a Maxwell Affair happen.

The problem was that the Maxwell scandal in fact had not been a pensions scandal at all - although it involved the theft of pension moneys. The missing money in the Maxwell Affair had been misappropriated not from the pension funds, but from regulated asset managers, regulated under the precursor of the Financial Services Authority. There were several lessons to be learnt from the scandal. One, that all the legislation in the world will not prevent a determined fraudster in the short term at least. And second, that the legislation was introduced under a misapprehension - the money had gone missing from a regulated institution, not a trust-governed pension fund.

That of course did not prevent the wave of regulation that hit the industry in 1997 (as well as the Act, there were getting on for 150 sets of pensions regulations made in 1995-1997, an unprecedented amount for any area of human activity). Nor did it prevent the ensuing waves. The Welfare Reform and Pensions Act 1999 (attachment and sharing of pensions on divorce, the state second pension, abolition of SERPS, stakeholders), the Child Support Pensions and Social Security Act 2000 (SERPS and S2P again, changes to contracting-out - again — combined benefit statements, changes to divorce rules, changes to money-purchase forecasts, changes to the powers of the regulator, changes to ombudsman procedures), much of which was not in the end implemented after all, the Pensions Act 2004 which was supposed to hoover up all the failings of the previous pensions legislation and simplify much of the earlier complications (by for example rewriting the former $\mathrm{s} 67$ (to do with the power of schemes to change their rules) by making it more than ten times longer and even more incomprehensible) and of course the Finance Act 2004.

The tax simplification story exemplifies the incoherent way in which reform took place. 
There was a general understanding that reform was needed in relation to taxation of pensions. Around 14 different pensions tax regimes, around 1,300 pages of rules, many of them very complicated, and problems in transferring rights from one scheme to another. The industry (the NAPF) issued a discussion document arguing for simplification, and reducing the length of the legislation from 1,300 pages to 2. For several years the HMRC ignored it; then in a spurt of enthusiasm decided to adopt it - but with a fatal flaw - introducing yet another cap, this time of around $\mathcal{L}_{1.5 \mathrm{~m}}$ of pension benefits in a lifetime. And for reasons which are even now hard to determine, the primary legislation is around 200 pages, the secondary legislation another 200 pages and there are around 3,200 pages of guidance notes, forgetting that the point of the reform was that the system would be so easy that such notes would be superfluous.

With all this legislation, call it around 5,000 pages of rules over the decade, one might expect that the public and the press would be comfortable with the safety and security of their retirement provision. And yet it clearly has not happened. We have had a decline in defined benefit systems, an inadequate replacement (if replacement at all) by much less beneficial defined contribution systems, with much less protection than the defined benefit arrangements, and very aggrieved press and public who have much less faith in the system than before, witness the travails of the ASW pensioners (whose miseries were mostly caused by the legislation passed to help them) and the almost monthly changes to the FAS.

One of the reasons has been the parallel rapid changes in the state pension system. There's little doubt the system did need fixing; it wasn't working. There was a basic state pension that offered some of the lowest such benefits in the EU, there was a SERPS system of such complexity that few understood it and where the computer system was struggling to administer it — and a third system, introduced in the Blair Years, the state pension credit system, which was means tested in two ways (one if you were rich, one if you were poor) and which was going to involve around $80 \%$ of the relevant cohort in filling in lengthy forms. So yet another report, this time from the Pensions Commission, was commissioned - and instead of supporting a long-term simplification of the system, it introduced a fourth state pension, now called Personal Accounts, whose computer system is unlikely to work. Instead of a simple citizens pension or its analogue, we have complicated the system yet again.

The Turner review of course while it crystallised the issues, notably lacked a clear vision for the future. But it wasn't the only review of the Blair Decade. We have enjoyed the Pickering Review on simplification, several Myners' Reviews, a slew of smaller reports on divorce, part-time working, age discrimination, civil partnership, gender recognition, bankruptcy, winding-up, discrimination on race, gender, sexual orientation, disability and belief, transfer values, contracting-out, protected rights, Higgs on corporate governance, Hampel on corporate governance, and employer task force on pensions, treatment of widowers and human rights, Equitable Life, actuarial professional codes, individual pension accounts (remember those?) reports on shareholder activism, various reports on the now defunct OPRA (remember them?) Partnership in Pensions, the annuities market, review of pensions institutions, the Pensions Education Working Group (remember them?) and many others. The problem has not been reform of a dysfunctional system; the problem has been digging up the daisies.

The daisy issue is the one that really lies at the crux of the Blair Years in pensions. It is not that the government lacked an appetite for fixing things that were wrong. Heaven knows there were things that were wrong that needed fixing. The problem was that despite pensions tax simplification (desperately needed and abominably implemented) and the Turner Commission, in fact there was no holistic review of the entire pensions situation. What should a state pension system do? What should a private pension system do? What tax system do we need to make it happen? But coupled with a lack of vision, we have had a hyperactive political establishment 
supported by a hyperactive civil service, staffed with intelligent people knowing they are doing things which are counterproductive but which will not find them out until they have moved on. Doing, perhaps, but not thinking.

What the Blair Years really lacked was a Beveridge, a holistic vision of what the retirement income scene should look like over the next 10, 20 or 30 years. The state system, perhaps more by luck than design, might yet eventually morph into a flat rate, non-means tested basic system, but the journey there will be a long and messy one. And the private sector pension system seems unstable for quite a while; neither party has a clear view on what it should look like, and both parties are determined to limit their thinking to sound-bite reforms to annuity rules, or to $401 \mathrm{ks}$ clones. It is all desperately sad.
Tony Blair himself may well be seen in many ways as one of the great prime ministers of the century; he made another political party electable, the country flourished economically, and the moral sense that enveloped him was a welcome change to the previous political cynicism. But the lack of strategic clarity in transport, defence, education, constitutional reform - and pensions - has cost the country a great deal. And as the population ages, and the voting power of the grey majority begins to be wielded, both the main political parties will regret their lost opportunities to put before the electorate a coherent, holistic, sensible, pragmatic, and manageable pension policy.

Robin Ellison

Editor 